\title{
A Brief Research Articles on Phytoplasma
}

\author{
Namita Singh* and Upadhyaya PP \\ Department of Botany, DDU Gorakhpur University, India
}

Submission: May 05, 2017; Published: August 07, 2017

*Corresponding author: Namita Singh, Department of Botany, DDU Gorakhpur University Gorakhpur- 273009, India, Email: namitasinghphd123@gmail.com

\begin{abstract}
Phytoplasma is a infectious agent in plant having cosmopolitan distribution and related to several types of plants diseases which cause severe epidemics of often quarantine purposes. Phytoplasma are prokaryotes belonging to the class Mollicutes because they lack a cell wall, up to now they were not cultivated in pure culture therefore Koch postulates are only sometimes fulfilled by using alternative tools, such as graft or insect transmission. The possibility to design specific primers for highly conserved genes such as 16S ribosomal gene together with the use of molecular probes randomly cloned from phytoplasma genome, allowed discriminating and molecularly classifying them. Now a certain amount of knowledge is available that allow starting epidemiological studies in order to prevent further spreading of phytoplasmaassociated diseases. In this paper molecular, biological and epidemiological characteristics of phytoplasma are described
\end{abstract}

\section{Introduction}

Phytoplasma are phloem colonizing prokaryotes, which are morphologically resembling mycoplasmaswas firstshownin 1967 [1]. Since they are, several hundreds of diseases are associated with the plants. Ribosomal rDNA sequencing provided evidence that these walls-less prokaryotes colonizing plant phloem and insects constitute a large monophyletic group within the class Mollicutes. The pathogen identification relied on microscopic observations (DAPI staining) or electron microscopy detection; DNA-based technology allowed to preliminary distinguishes different molecular clusters inside these prokaryotes. The Phytoplasma Working Team of the International Research Project for Comparative Several plant species show malformations associated with phytoplasma presence Mycoplasmology [2]. The trivial name 'phytoplasma' to identify the prokaryotes belonging to this group, the "Candidatus Phytoplasma" genus has been proposed and adopted in order to start formal classification of these prokaryotes, some of them associated with important or quarantine-subjected plant diseases. Up to date satisfaction of Koch postulates has not been achieved, but indirect proof, such as phytoplasma and symptoms eliminating after tetracycline treatments, confirmed that they are associated with many plant diseases worldwide; it was also demonstrated that genetically undistinguishable phytoplasmas can be associated with diseases inducing different symptoms and/or affecting different plant species, and also that different phytoplasmas can be associated with similar symptoms in the same or in different plant host. Plants infected by phytoplasmas exhibit an array of symptoms that suggests profound disturbances in the normal balance of growth regulators $[3,4]$. Symptoms include virescence/phyllody (development of green leaf like structures instead of flowers), sterility of flowers, proliferation of axillary buds resulting in a witches' broom behavior, abnormal internodes elongation, generalized stunting. Phytoplasmas are wall less prokaryotes with sizes variable from $600 \mathrm{~nm}-1 \mu \mathrm{m}$, they are pleiomorphic in nature, and could survive and multiply only in hysotonic habitats, such as plant phloem or insect emolymph, therefore they are strictly host-dependent, but they could multiply in insect vectors and also infect their eggs. The phytoplasma chromosome is very small (680-1,600kb) and phylogenetic studies propose that the common ancestor for phytoplasmas is Acholeplasma laidlawii in which the triplet coding for tryptophan (trp) is UGG, while in the other prokaryotes, enclosing mycoplasmas and spiroplasmas, trp is coded by UGA. Phytoplasmas are genetically distinguishable from mycoplasmas infecting human and animal for the presence of a spacer region (about $300 \mathrm{bp}$ ) between $16 \mathrm{~S}$ and $23 \mathrm{~S}$ ribosomal regions, which codes isoleucine tRNA (tRNAIle) and part of the sequences for alanine tRNA (tRNAAla). Sequencing of complete rRNA genes for two phytoplasma strains shows that tRNA coding for valine and asparagines are located downstream from the $5 \mathrm{~S}$ rRNA gene, and this is a unique feature of phytoplasmas [2].

\section{Identification with Molecular Detection}

The use of sensitive techniques such as PCR and nestedPCR appears to be very important to study these prokaryotes; however dot-hybridisation and RFLP analyses of total genomic 
DNA provided first evidences for phytoplasma differentiation. Sequence analyses of the 16SrDNA allow producing a detailed picture of phytoplasma diversity and of their Phylogenetic relationships with other prokaryotes; numerous studies carried out on this gene in several phytoplasmas led to the conclusion that they are a unique monophyletic group of Mollicutes that could be indicated by the new name of phytoplasmas. This name emphasises the Phylogenetic distance of these prokaryotes from some of the mycoplasmas infecting animals and humans. According to the recommendations of the International Committee of Systematic Bacteriology, subcommittee on the Taxonomy of Mollicutes a new Candidatus species may be described when a $16 \mathrm{~S}$ rDNA sequence (longer than 1200bp) has less than $97.5 \%$ identity with any previously described Candidatus species. Also two phytoplasmas sharing more than $97.5 \%$ of $16 \mathrm{~S}$ sequence can be designed as separate Candidatus species when they meet the comparing similar regions in two phytoplasmas and in phylogenetically closer relatives showed that different organization at this level clearly distinguish phytoplasmas from other phylo genetically related Mollicutes. DNA for phytoplasma detection and identification must be extracted from plant midribs or phloem in which phytoplasma titre is usually higher but always lower than $1 \%$ of DNA extracted. Several protocols have been described, but usually a chloroform/phenol extraction followed by isopropanol precipitation protocol provides useful results for the majority of plant species tissues. Shorter procedures can be adopted for routine testing of insects, but the DNA will be difficult to maintain for long-time. It is advisable to control nucleic acid quality before performing PCR in order to avoid possible inhibitor presence that is quite common, especially when the extraction is performed from woody host plants, in certain periods of the year (Winter/Spring), or after spraying of plants with pesticides. Direct-PCR followed by nested-PCR assays with internal primer pairs designed on $16 \mathrm{~S}$ ribosomal region of phytoplasmas allows detecting phytoplasmas presence in field collected samples from herbaceous as well as from woody host plants, and from insect potential or vector of phytoplasma-associated diseases as well. PCR conditions are slightly different in agreement with primer pairs employed, but for the complete identification of detected phytoplasma, it is necessary to perform RFLP analysis of $16 \mathrm{~S}$ rDNA amplicons. Using these tools finally researches on phytoplasma have become possible in many laboratories and to start validation of important knowledge about taxonomy [2].

\section{Conclusion}

Phytoplasmas are fascinating super micro-organisms, capable to adapt their life at least two different habitats animal (insect) and plant cell. The phytoplasma-related researches are still in their infancy, several tasks could be fulfilled in order to acquire a clear knowledge of the situations types of symptoms, their identification for control of disease spreading and their transmission. The sequencing of complete phytoplasma genome, after its full annotation, will provide more precise basis for taxonomy and genomic properties, its phylogeny but it will be necessary to do it for several other phytoplasmas in order to achieve comparative genomic analysis that could allow a deeper understanding about physiology of these organisms., it seems to be the only possible research for phytoplasma classification and identification since it is still difficult to fulfill the minimal requirement for a formal taxonomy, not only because they are not cultivable in -vitro, but also because of their low titre in the infected plants. The dreams and the hopes of some researchers were devoted to phytoplasma cultivations in order to gain more consistent knowledge about these pathogens or in general about these prokaryotes. This should be the next step to be achieved by researchers that will help to better understanding not only plant-pathogen interactions but also safeness of using some phytoplasma for economically useful purposes and what's changes in biochemical properties and its physiology. The phytoplasma genome encodes even fewer metabolic functions than do mycoplasma genomes. It lacks the pentose phosphate cycle and, more unexpectedly, ATP-synthase subunits, which are thought to be essential for life. This may be the result of reductive evolution as a consequence of life as an intracellular parasite in a nutrient-rich environment insects and plants are hosts of the phytoplasmas but a third part of the "story" should be considered the microbial community in plant. The importance of these pathogens is linked to their "activity" in plant as pathogen. They are able to cause severe diseases of great economic impact on our staple crops other eco-balancing plant.

\section{References}

1. Doi Y, Teranaka M, Yora K, Asuyama H (1967) Mycoplasma or PLT grouplike microrganisms found in the phloem elements of plants infected with mulberry dwarf, potato witches' broom, aster yellows or pawlownia witches' broom. Ann Phytopath Soc Japan 33: 259-266.

2. IRPCM Phytoplasma/Spiroplasma Working Team-Phytoplasma taxonomy group (2004) Description of the genus 'Candidatus Phytoplasma', a taxon for the wall-less nonhelical prokaryotes that colonize plant phloem and insects. Int J Syst Evol Microbiol 54: 12431255.

3. Panda RK (1995) Role of auxins on the egg plant infected with mycoplasma. Adv Pl Sci 8: 248-252.

4. Pertot I, Musetti R, Pressacco L, Osler R (1998) Changes in indole-3acetic acid level in micropropagated tissues of Catharanthus roseus infected by the agent of the clover phyllody and effect of exogenous auxins on phytoplasma morphology. Cytobios 95: 13-23. 
This work is licensed under Creative Commons Attribution 4.0 Licens

DOI: 10.19080/IJCSMB.2017.02.555559
Your next submission with Juniper Publishers will reach you the below assets

- Quality Editorial service

- Swift Peer Review

- Reprints availability

- E-prints Service

- Manuscript Podcast for convenient understanding

- Global attainment for your research

- Manuscript accessibility in different formats ( Pdf, E-pub, Full Text, Audio)

- Unceasing customer service

Track the below URL for one-step submission https://juniperpublishers.com/online-submission.php 